\title{
EFEKTIFITAS SENAM HAMIL DALAM PERCEPATAN DURASI KALA II PADA PERSALINAN PERVAGINAM IBU PRIMIGRAVIDA
}

\author{
Effectiveness of Pregnancy Exercises in Accelerating the Duration of Second Stage in Vaginal \\ Delivery of Primigravida
}

\author{
Kolifah $^{1}$
}

${ }^{1}$ Stikes Pemkab Jombang

Riwayat artikel

Diajukan: Agustus 2021

Diterima: September 2021.

\section{PenulisKorespondensi:}

- Kolifah

- Stikes Pemkab Jombang

- kolifah0607@gmail.c om

\section{Kata Kunci:}

Dukungan Suami,

Dukungan Kader

Posyandu, Minat Ibu, Alat

Kontrasepsi Implan

\section{Abstrak}

Derajat kesehatan suatu Negara dapat dilihat dari kesehatan ibu dan anak. Kematian ibu di dunia menurut WHO sangat tinggi, setiap hari di dunia terdapat wanita meninggal karena komplikasi kehamilan atau persalinan. Persalinan yang alami dan lancar dapat dicapai jika otot panggul dapat terus berkontraksi dengan baik, ritmis dan kuat. Senam hamil yang dilakukan secara teratur akan melatih otot panggul dan otot jalan lahir, sehingga memperlancar pengeluaran janin. Tujuan penelitian mengetahui efektifitas senam hamil dalam percepatan durasi kala II pada persalinan pervaginam ibu primigravida.

Jenis penelitian observasional desain korelasi dengan pendekatan retrospektif. Populasi seluruh ibu primigravida yang melahirkan di PMB ' $\mathrm{R}$ " Jombang, dengan purposive sampling didapatkan sampel $38 \mathrm{ibu}$ bersalin. Variabel bebas adalah senam hamil dan variabel terikat adalah durasi kala II persalinan. Instrumen penelitian lembar wawancara dan observasi persalinan. Data dianalisa uji korelasi chi square.

Hasil penelitian menunjukkan sebagian besar $(81,6)$ responden melaksanakan senam hamil yaitu 31 responden, sebagaian besar $(76,3 \%)$ responden dengan lama Kala II normal yaitu 29 responden. Ada hubungan senam hamil dengan lama kala II pada ibu Primigravida, $p$ value $=0,000$ dan nilai $\mathrm{r}=0,57$.

Ibu hamil yang melakukan senam hamil sejak awal dan dilakukan secara berkesinambungan menjadikan otot dinding perut, ligamen, otot dasar panggul dan otot sekitarnya menjadi kuat sehingga proses persalinan menjadi lebih cepat dengan adanya koordinasi yang baik antara his, kontraksi dan otot otot panggul.

\section{Abstract}

The health status of a country can be seen from the health of mothers and children. According to WHO, maternal mortality in the world is very high, every day in the world there are women who die from complications of pregnancy or childbirth. A natural and smooth delivery can be achieved if the pelvic muscles can continue to contract properly, rhythmically and strongly. Pregnancy exercise that is done regularly will train the pelvic muscles and the muscles of the birth canal, thus facilitating the expulsion of the fetus. The purpose of this study was to determine the effectiveness of pregnancy exercise in accelerating the duration of the second stage of vaginal delivery for primigravida mothers. This type of research is an observational correlation design with a retrospective approach. The population of all primigravida 
mothers who gave birth at $P M B$ ' $R$ " Jombang, with purposive sampling obtained a sample of 38 mothers who gave birth. The independent variable is pregnancy exercise and the dependent variable is the duration of the second stage of labor. The research instruments were interview sheets and labor observations. Data were analyzed by chi square correlation test. The results showed that most (81.6) respondents carried out pregnancy exercise, namely 31 respondents, most (76.3\%) respondents with normal duration of Second Stage, namely 29 respondents. There is a relationship between pregnancy exercise and the length of the second stage in Primigravida mothers, $p$ value $=0.000$ and $r$ value $=0.57$. Pregnant women who do pregnancy exercise from the beginning and are carried out continuously make the abdominal wall muscles, ligaments, pelvic floor muscles and surrounding muscles strong so that the delivery process becomes faster with good coordination between the muscles, contractions and pelvic muscles Keywords: Pregnancy exercise, Second stage, Primigravida 


\section{Pendahuluan}

Janin, jalan lahir dan tenaga perdalinan menjadi hal yang penting dalam proses persalinan. Perlu adanya sutau tindakan untuk mengendalikan tigal hal tersebut agar terkoordinasi dengan baik. Senam juga merupakan bentuk metode koping yang dapat menghindarkan terjadinya stress fisik akibat kehamilan, seperti mengurangi kram kaki, dan punggung, meningkatkan kemampuan ibu untuk adaptasi dengan adanya perubahan pada tubuhnya. Oleh karenanya American College of Obstetricans and Gynecologist (ACOG) merekomendasikan senam sebagai upaya preventif pada ibu agar proses kahamilan dan persalinan berjalan secara alamiah, dan mengurangi krisis akibat persalinan (Clapp, 2005)

Lama waktu proses persalinan berbeda antara primipara dan multipara, salah satu yang mempengaruhinya adalah elastisitas otot dinding perut dan otot otor panggul. (1)

Senam hamil yang dilakukan untuk ibu hamil sehat membantu fisik ibu untuk proses persalinan dengan mempersiapkan otot otot yang berperan dalam persalinan, serta psikologis ibu dengan meningkatkan rasa percaya diri menghadapi persalinan. (2)

AKI di Indonesia dari 390 pada tahun 1991 menjadi 305 pada tahun 2015. Angka Kematian Ibu (AKI) tahun 2016 di Provinsi Jawa Timur mencapai 91,00 per 100.000 kelahiran hidup. Angka ini mengalami peningkatan dibandingkan tahun 2015 yang mencapai 89,6 per 100.000 kelahiran hidup, penyebab kematian tertinggi pada ibu tahun 2016 adalah pre eklamsia / eklamsia sebesar $30,90 \%$ dan perdarahan $24,72 \%$.

Hasil penelitian Atika (2015) dari 47 responden yang mengikuti senam hamil, diperoleh bahwa sebagian besar 80,9\% responden waktu persalinanya normal antara $4-18$ jam, 14,9\% persalinan presipitatus yaitu $<3$ jam dan 4,3\% persalinan lama yaitu $>18$ jam.

Hasil penelitian dari Widyawati \& Syahrul (2012) menunjukkan pengaruh senam hamil terhadap lama persalinan, yaitu ibu yang melakukan senam hamil memiliki kemungkinan lama persalinan lebih cepat di bandingkan ibu hamil yang tidak melakukan senam hamil. Hal ini serupa dengan penelitian Rahmawati (2016) menyatakan bahwa ada hubungan senam hamil terhadap lamanya proses persalinan.

Penelitian Katrhi et al (2014) menunjukkan adanya perbedaan yang significan dalam durasi persalinan antara wanita yang melakukan latihan senam hamil dan yang tidak melakukan senam hamil. Kelompok yang tidak melakukan senam hamil memiliki durasi persalinan lebih dari 12 jam dan kelompok yang melakukan senam hamil memiliki durasi kurang dari 12 jam.

Haryono (2010) menyatakan bahwa durasi partus kala II pada ibu-ibu yang melakukan senam hamil terbukti lebih pendek dibandingkan dengan ibu-ibu yang tidak melakukan senam hamil. Ibu-ibu yang tidak melakukan senam hamil memiliki kemungkinan dua kali lebih besar mengalami partus lama.

Persalinan yang alami dan lancar dapat dicapai jika otot otot panggul dapat terus berkontraksi dengan baik, ritmis dan kuat. Senam hamil yang dilakukan secara teratur akan memperkuat otot dinding perut, ligamen, otot dasar panggul dan otot sekitarnya sehingga pada saat proses persalinan dapat berkontraksi secara sinergis sehinga timbulkan dorongan kuat pada janin.

Upaya pemerintah dalam menurunkan angka morbiditas dan mortalitas ibu adalah mengadakan program pelayanan antenatal terpadu. Pelayanan antenatal terpadu adalah pelayanan antenatal komprehensif dan berkualitas yang diberikan kepada semua ibu hamil. Salah satu intervensi kesehatan yang efektif adalah pelayanan antenatal yaitu senam hamil. Bidan dalam melakukan pelayanan pada ibu hamil memiliki wewenang untuk membimbing dalam melakukan senam hamil (Depkes RI, 2012). 


\section{Metodologi}

Jenis penelitian observasional desain korelasi dengan pendekatan retrospektif. Populasi ibu primigravida yang melahirkan di PMB " $\mathrm{R}$ " Jombang dengan purposive sampling didapatkan sampel $38 \mathrm{ibu}$ bersalin. Variabel bebas adalah senam hamil dan variabel terikat adalah lama kala II persalinan. Instrumen penelitian lembar wawancara dan observasi persalinan. Data dianalisa uji korelasi chi square.

\section{Hasil dan Pembahasan}

Data diskriptif diperoleh distribusi responden berdasarkan umur, pendidikan, pekerjaan, sumber informasi, usia kehamilan, kunjungan ANC.

Tabel 1 Distribusi Frekuensi Responden Umur, Pendidikan, Pekerjaan, Sumber Informasi, Usia Kehamilan dan Kunjungan ANC.

\begin{tabular}{lcc}
\hline \multicolumn{1}{c}{ Variabel } & f & \% \\
\hline$<20$ tahun & 1 & 2,6 \\
$20-35$ tahun & 35 & 92,1 \\
$>35$ tahun & 2 & 5,3 \\
\hline Pendidikan Dasar & 4 & 10,5 \\
Pendidikan Menengah & 28 & 73,7 \\
Pendidikan Tinggi & 6 & 15,8 \\
\hline Tidak pernah & 0 & 0 \\
Pernah & 38 & 100 \\
\hline Radio / TV & 2 & 5,3 \\
Petugas Kesehatan & 36 & 94,7 \\
Koran / Majalah & 0 & 0 \\
\hline Ibu rumah tangga & 20 & 52,6 \\
Petani & 1 & 2,6 \\
Wiraswasta & 9 & 23,7 \\
PNS & 8 & 21,1 \\
\hline $36-38$ minggu & 7 & 18,4 \\
$38-40$ minggu & 30 & 78,9 \\
$>$ 40 minggu & 1 & 2,6 \\
\hline Tidak teratur & 6 & 15,8 \\
Teratur & 32 & 84,2 \\
& &
\end{tabular}

Tabel diatas menunjukkan bahwa sebagian besar $(92,1 \%)$ responden berusia 20 - 35 tahun yaitu 35 responden, sebagian besar $(73,7 \%)$ status pendidikan responden berpendidikan menengah (SMA) yaitu 28 responden, seluruhnya (100\%) responden pernah mendapatkan informasi tentang senam hamil yaitu 38 responden, hasil hampir seluruhnya $(94,7 \%)$ responden mendapatkan informasi tentang senam hamil dari tenaga kesehatan yaitu 36 responden, sebagian besar $(52,6 \%)$ responden sebagai ibu rumah tangga yaitu 20 responden, sebagian besar $(78,9 \%)$ responden dengan usia kehamilan 38 - 40 minggu yaitu 30 responden dan hampir seluruhnya $(84,2 \%)$ responden teratur melakukan kunjungan ANC yaitu 32 responden.

Pelaksanaan Senam Hamil pada ibu Primigravida.

Tabel 2. Distribusi Frekuensi pelaksanaan Senam Hamil

\begin{tabular}{lcc}
\hline \multicolumn{1}{c}{ Senam hamil } & f & \% \\
\hline Tidak Senam Hamil & 7 & 18,4 \\
Senam Hamil & 31 & 81,6 \\
\hline Total & 38 & 100 \\
\hline
\end{tabular}

Tabel 3. Distribusi Frekuensi Responden Berdasarkan lama Kala II.

\begin{tabular}{lcc}
\hline Lama kala II & f & \% \\
\hline Kala II Memanjang & 9 & 23,7 \\
Kala II Normal & 29 & 76,3 \\
\hline Total & 38 & 100 \\
\hline
\end{tabular}

Tabel 3. Tabulasi silang antara senam hamil dengan lama Kala II pada ibu Primigravida.

\begin{tabular}{|c|c|c|c|c|c|c|}
\hline \multirow{3}{*}{ Senam hamil } & \multicolumn{4}{|c|}{ Lama Kala II } & \multirow{2}{*}{\multicolumn{2}{|c|}{$\sum$}} \\
\hline & \multicolumn{2}{|c|}{$\begin{array}{c}\text { Kala II } \\
\text { Memanjang }\end{array}$} & \multicolumn{2}{|c|}{$\begin{array}{c}\text { Kala II } \\
\text { Normal } \\
\end{array}$} & & \\
\hline & f & $\%$ & f & $\%$ & $\mathrm{f}$ & $\%$ \\
\hline $\begin{array}{l}\text { Tidak senam } \\
\text { hamil }\end{array}$ & 6 & 85,7 & 1 & 14,3 & 7 & 100 \\
\hline Senam hamil & 3 & 9,7 & 28 & 90,3 & 31 & 100 \\
\hline Jumlah & 9 & 23,7 & 29 & 76,3 & 38 & 100 \\
\hline
\end{tabular}

Hasil uji statistic Chi Square menunjukkan bahwa $p$ value adalah 0,000, maka H1 diterima artinya ada hubungan antara senam hamil dengan lama Kala II pada ibu primigravida. Coefficient Contingency menunjukkan 0,57 yang artinya antara senam hamil dan lama kala II memiliki kekuatan hubungan yang sedang.

Pelaksanaan senam hamil pada ibu primigravida. Hasil penelitian didapatkan bahwa sebagian besar $(81,6 \%)$ responden 
melaksanakan senam hamil yaitu 31 responden.

Senam hamil merupakan salah satu bentuk latihan yang diberikan pada ibu hamil, senam hamil akan memberikan dampak yang lebih baik selama proses persalinan, dengan mengurangi dan mengendalikan faktor penyebab persalinan memanjang dengan cara meningkatkan kekuatan ibu pada saat mengejan. Dengan senam hamil, otot otot dan persendian yang berperan dalam proses persalinan, menjadi lebih kuat elastisitas. Mekanisme persalinan yang baik diperlukan koordinasi antara otot dinding perut, otot dasar panggul, dan ligament yang baik, selain itu diperlukan sikap tubuh yang prima (Manuaba, 2010).

Responen melaksanakan senam hamil teratur yaitu ibu hamil yang melakukan senam minimal 3 kali dalam satu minggu dan senam hamil teratur mulai dilaksanakan sejak kehamilan 24 minggu. Responden disebut tidak senam jika ibu tidak pernah melakukan senam hamil, atau senam yang tidak teratur, jika ibu melakukan senam hamil kurang dari 3 kali dalam satu minggu atau senam dimulai pada usia kehamilan 36 minggu.

Hasil penelitian didapatkan bahwa hampir seluruhnya $(92,1 \%)$ responden berusia 20 - 35 tahun yaitu 35 responden.

Masa dewasa dini pada rentang usia 20 35 tahun merupakan periode peyesuaian diri terhadap pola-pola kehidupan baru dan dikenal dengan masa kreatif dimana individu memiliki kemampuan mental untuk mempelajari dan menyesuaikan dari situasi baru, sepeti mengingat hal-hal yang pernah dipelajari, penalaran analogis, berpikir kreatif serta belum terjadi penurunan daya ingat (Hurlock (2016).

Usia produktif seorang wanita untuk hamil dengan sehat dan sedikit resiko yaitu pada usia $20-35$.

Penelitian yang dilakukan Laili (2015) menyatakan bahwa umur ibu berhubungan dengan keikutsertaan dalam pelaksanaan senam hamil dengan $\rho=0,001$. Semakin cukup umur, tingkat kematangan dan kekuatan seseorang akan lebih matang dalam berpikir dan bekerja.

Hasil penelitian didapatkan bahwa sebagian besar $(73,7 \%)$ status pendidikan responden berpendidikan menengah (SMA) yaitu 28 responden.

Menurut Nototatmodjo (2013), bahwa pendidikan merupakan salah satu faktor yang mempengaruhi pengetahuan. Pengetahuan melandasi sikap yang akan mendorong perilakunya. Dengan demikian, pendidikan yang dimiliki oleh ibu hamil dapat melandasi sikapnya yang akan mendorong perilaku ibu hamil untuk mengikuti senam hamil. Seseorang yang mempunyai pendidikan lebih tinggi akan lebih mudah menerima informasi yang disampaikan oleh tenaga kesehatan. Artinya, ia dapat mengadopsi inovasi dengan cepat dibandingkan dengan ibu-ibu berlatar belakang pendidikan rendah yang cenderung sulit untuk mengetahui atau mengikuti informasi yang tersedia dengan keterbatasan pengetahuan (Notoatmodjo, 2013).

Hal ini sesuai dengan hasil penelitian Anasari (2011) ada hubungan tingkat pendidikan ibu hamil dengan keikutsertaan ibu hamil dalam melakukan senam hamil pada kelas ibu hamil $(p=0,005)$.

Hasil penelitian yang sebagian besar responden mimiliki pendidikan menengah memiliki informasi yang baik tentang senam hamil sehingga memilih untuk ikut melaksanakan senam hamil.

Hasil penelitian didapatkan hasil sebagaian besar $(76,3 \%)$ responden dengan lama Kala II Normal (kurang dari 2 jam) yaitu 29 responden. Persalinan kala II dimulai dengan pembukaan lengkap dari serviks dan berakhir dengan lahirnya bayi. Proses ini berlangsung 2 jam pada primi dan 1 jam pada multi (Varney, 2013).

Proses kala II akan berjalan dengan normal yaitu maksismal 2 jam pada ibu primigravida jika otot otot bawah Rahim ibu secara reflektoris siap dilalui oleh janin dan ibu memiliki kekuatan untuk mengejan dengan baik. Hal ini dapat dimiliki oleh ibu jika ibu hamil rutin melaksanakan senam hamil. Persalinan kala II akan berjalan 
dengan normal selama tidak ada komplikasi dan penyulit yang terjadi pada ibu inpartu. Jika terdapat penyulit dalam proses persalinan maka lama kala II akan melebihi dari batas waktu yang normal sehingga diperlukan tindakan untuk mengakhiri persalinan.

Hasil penelitian didapatkan bahwa dari total 31 responden yang melakukan senam hamil didapatkan bahwa hampir seluruhnya (90,3\%) responden yaitu 28 responden lama Kala II Normal, sedangkan dari total 7 responden yang tidak melakukan senam hamil didapatkan bahwa hampir seluruhnya $(85,7 \%)$ lama kala II memanjang yaitu 6 responden. Hasil uji statistic chi Square menunjukkan bahwa $p$ value adalah 0,000, maka H1 diterima artinya ada hubungan antara senam hamil dengan lama Kala II pada ibu primigravida.

Varney (2013) menjelaskan bahwa persalinan yang alami dan lancar dapat dicapai jika otot otot panggul dapat terus berkontraksi dengan baik, ritmis dan kuat. Senam hamil yang dilakukan secara teratur akan memperkuat otot dinding perut, ligamen, otot dasar panggul dan otot sekitarnya sehingga pada saat proses persalinan dapat berkontraksi secara sinergis sehinga timbulkan dorongan kuat pada janin. Lamanya proses persalinan dapat dipengaruhi oleh tiga hal yaitu tenaga, jalan lahir dan janin. Sampai saat ini yang dapat dikendalikan adalah masalah tenaga atau power, yaitu ditingkatkan dengan senam hamil. Senam atau latihan selama kehamilan memberikan efek positif terhadap pembukaan serviks dan aktivitas uterus yang terkoordinasi saat persalinan, juga ditemukan secara bermakna onset persalinan yang lebih awal dan lama persalinan yang lebih singkat dibandingkan dengan yang tidak melanjutkan senam hamil. Senam hamil dapat membantu persalinan sehingga ibu dapat melahirkan tanpa kesulitan, serta menjaga ibu dan bayi sehat setelah melahirkan.

Hasil penelitian Atika (2013) dari 47 responden yang mengikuti senam hamil, diperoleh bahwa mayoritas $80,9 \%$ responden waktu persalinanya normal antara 4 - 18 jam, 14,9\% persalinan presipitatus yaitu $<3$ jam dan $4,3 \%$ persalinan lama yaitu > 18 jam. Penelitian Katrhi et al (2015) menunjukkan adanya perbedaan yang significan dalam durasi persalinan antara wanita yang melakukan latihan senam hamil dan yang tidak melakukan senam hamil dengan nilai $\mathrm{p}$ value $=0,003(\mathrm{p}<0,005)$. Kelompok yang tidak melakukan senam hamil memiliki durasi persalinan lebih dari 12 jam dan kelompok yang melakukan senam hamil memiliki durasi kurang dari 12 jam. Hasil penelitian Rahmawati (2016) menyatakan bahwa ada hubungan senam hamil terhadap lamanya proses persalinan dengan $\mathrm{p}$ value sebesar 0,012 ( $\mathrm{p}<0,05)$ pada ibu bersalin di wilayah kerja Puskesmas Bayat Klaten.

Nirwana (2011) senam hamil adalah terapi latihan gerakan untuk mempersiapkan ibu hamil secara fisik dan mental,pada persalinan cepat, aman dan spontan. senam hamil di anjurkan pada usia kehamilan memasuki usia 6 bulan ke atas. Bagi ibu hamil yang baru pertama kali hamil (primigravida) atau sudah pernah hamil (multigravida), sangat disarankan mengikuti program senam hamil demi kesehatan ibu dan janin (Aprilia, 2019).

Ibu hamil yang melaksanakan senam hamil secara rutin mengakibatkan otot otot dasar panggul menjadi lebih lentur dan siap menjalani proses persalinan, karena gerakan dalam senam hamil bertujuan untuk meningkatkan elastisitas dinding perut. Senam hamil juga mengurangi rasa nyeri selama proses persalinan karena ibu telah terlatih proses kontraksi dan relaksasi. Begitu juga dengan pernafasan ibu bersalin menjadi lebih kuat dan dalam sehingga kekuatan ibu cukup untuk mendorong janin keluar dari jalam lahir. Manfaat dari senen hamil itulah yang memperlancar dan mempercepat proses persalinan kala II.

Ibu yang dapat melalui kala II dengan normal tidak terlalu lama dan tidak terlalu cepat, menunjukkan bahwa ada kesinergisan antara segmen atas rahim dan segmen bawah rahim, sehingga janin terdorong ke bawah 
dan terjadi relaksasi pada pintu bawah rahim sehingga janin dapat keluar dengan lancar.

\section{Simpulan}

Pelaksanaan senam hamil efektif dalam mempercepat durasi kala II pada ibu Primigravida. Penelitian selanjutnya dapat di tingkatkan dengan melihat pengaruh senam hamil terhadap percepatan involusi pada ibu nifas sehingga akan memotivasi ibu hamil untuk melakukan senam hamil secara teratur.

\section{Daftar Pustaka}

Anasari (2011) Analisis Faktor - Faktor yang Berhubungan Dengan Keikutsertaan Ibu Hamil Dalam Melakukan Senam Hamil pada Kelas Ibu Hamil. Internet available http://digilib.unisayogya.ac.id/4289/1/ NASKAH\%20PUBLIKASI_Yunita.T L_1710104139.pdf. Diakses 20 Mei 2019

Amalina, Nur Atika. (2015) Hubungan Rutinitas senam Hamil dengan waktu persalinan pervaginam pada primigravida di Rumah Sakit Panti Wilasa Semarang. Internet available from

http://repository.unimus.ac.id/224/1/At ika\%20Nur\%20A..pdf diakses 17 Januari 2019.

Atika (2013) Senam Hamil dengan. Kelancaran. Persalinan Normal Di. Wilayah. Kerja di kota Malang. Internet available http://repository.unimus.ac.id/224/1/At ika\%20Nur\%20A..pdf. Diakses 15 Mei 2019

Clapp, James F. 2005. The effect of continuing regular exercise on the physiologic adaptations to pregnancy outcome. The American Journal of Sport Medicine, 24: 6 p 28 (2).
Hurlock EB. (2011) Psikologi Perkembangan: Suatu Pendekatan Sepanjang Rentang Kehidupan. Edisi Kelima. Jakarta: Erlangga

Kementerian Kesehatan (2013) Laporan Nasional Riset Kesehatan Dasar 2013 Jakarta: Badan Litbang Kesehatan;. Internet available from: http://www.litbang.depkes.go.id/sites/ download/rkd2013/LaporanRiskesdas 2013. PDF. Diakses tanggal 25 Januari 2019.

Laili, uliyatul. (2015). Analisis faktor faktor yang mempengaruhi keikutsertaan senam hamil pada ibu hamil di BPS Nina Surabaya. Journal of health UNUSA Vol.8 no.2 tahun 2015.

Available internet http://journal.unusa.ac.id/index.php/jh s/article/view/66

Manuaba, I.B.G, dkk. (2010). Ilmu Kebidanan, penyakit kandungan dan KB. Jakarta: EGC.

Notoadmodjo, Soekidjo. (2012). Metodologi Penelitian Kesehatan cetakan ke 3. Jakarta : Rineka Cipta

Notoatmodjo, Soekidjo. (2013). Ilmu Perilaku Kesehatan. Jakarta : Rineka Cipta

Romauli, Suryati. 2011. Buku Ajar ASKEB I: "Konsep Dasar Asuhan Kehamilan”. Yogyakarta: Nuha Medika.

Rahmawati, Nur Aini; Sutaryono ; Sri Lestari. (2016) Hubungan Senam Hamil terhadap lamanya proses persalian pada ibu bersalin di wilayah Kerja Puskesmas Bayat Klaten. Jurnal Involusi Kebidanan, Vol. 6, No. 11, Januari 2016. Internet available from http://ejournal.stikesmukla.ac.id/index. php/involusi/article/download/202/200 diakses 20 Januari 2019. 
Salfariani I, 2012. Nasution S-S. Caesarea Tanpa Indikasi Medis di RSU Bunda Thamrin Medan. J Keperawatan Klin. Internet available from: https://jurnal.usu.ac.id/index.php/jkk/a rti cle/view/94. Diakses tanggal 20 Januari 2019

Varney, Helen. (2013) Buku Ajar Asuhan kebidanan Volume 1. Jakarta EGC

Varney, Helen. (2013) Buku Ajar Asuhan kebidanan Volume 2. Jakarta EGC

Widyawati, Fariani Syahrul, Pengaruh Senam Hamil Terhadap Prose Persalinan dan Status Kesehatan Neonatus. Jurnal Berkala Epidemiologi, Vol. 1, No. 2 September 2013: 316-324 